(RESEARCH ARTICLE)

\title{
Mycological and mycotoxicological quality assessment of dried meat (Kilishi) sold in Kebbi state, Nigeria
}

\author{
Kasimu Shehu 1, Ibrahim Alhaji Salau 2,* and Naziru Salisu 1 \\ ${ }^{1}$ Department of Biology, Federal University, Birnin-Kebbi, Kebbi State Nigeria \\ 2 Department of Biological Sciences, Federal University Gusau, Zamfara State Nigeria.
}

Publication history: Received on 30 August 2020; revised on 25 September 2020; accepted on 27 September 2020

Article DOI: https://doi.org/10.30574/wjarr.2020.8.1.0331

\begin{abstract}
This study assessed the mycological quality of dry meat products in three Emirates of Kebbi, Nigeria. A total of 63 dry meat samples were collected through systematic random sampling; twenty one samples from each Emirate. The standard method of isolating micro-organisms was adopted. The total viable count obtained ranged from $1.0 \times 10^{3}-3.7$ $\mathrm{x} 10^{3}$. Eight different fungi were found associated with the dried meat samples sold in the three different Emirates. The associated fungi were Aspergillus flavus, Aspergillus fumigatus, Absidia sp., Rhizopus sp., A. niger, Mucor sp., Cladosporium sp, Penicillium sp. Aspergilus flavus and A. niger had the highest rate of occurrence among the isolated fungi. Mycotoxicologically, Ochratoxin were positive for $71 \%$ samples and concentration ranged of $0.2-14.0 \mu \mathrm{g} / \mathrm{kg}$, Fumonisin were positive for $52.4 \%$ samples at concentration ranged of $0.2-31.0 \mu \mathrm{g} / \mathrm{kg}$, while $19 \%$ samples had mycotoxin concentrations above the European Union maximum tolerance level of $4 \mu \mathrm{g} / \mathrm{kg}$. It is obvious that dried meat products sold in Kebbi are potentially contaminated; proper hygiene practices should be observed during handling, marketing and calls for concerted efforts on the part of relevant authorities to check the trend, since it is a public health challenge.
\end{abstract}

Keywords: Kebbi Emirates; Dried meat; Mycotoxin, Fumonisins; Ochratoxin and Fungi

\section{Introduction}

Meat is one of the most popular and known food items which come from flesh of animals that are suitable as food [1]. Different kinds of meat exist as a result of their methods of preparation and preservation. In Nigeria, the most common name for dried meats are Tinko, Kilishi and Kundi majority prepared by peoples of Northern Nigeria [2]. Meat surface is usually heavily contaminated with a wide range of microorganisms due to its chemical composition which includes; water content, peptides, sugars, amino acids, nucleosides, mineral and vitamins. This composition makes the meat a suitable medium for the growth of microorganisms [3]. In this part of the world (Nigeria), meat is preserved by sundrying after cooking or smoking. Dried meat "Tinco" can be preserved by regular sun-drying, salting and prevention of moisture being absorbed into the meat product. Traditionally, dried meat microbiology involves a natural development of wild fermentation in which microbial successions occur, uniform salting over the entire surface is most critical to inhibit pathogens and spoilage organisms [2].

Moreover, dried meats displayed in the market are found to be visibly mouldy (high level of discolouration). Most of these meats are produced from the Northern part of Nigeria and are transported to the South in small packages such as woven sisal bags, jute sacks and baskets. They invariably become mouldy before reaching the market. The presence of moulds in the meat products usually causes a decrease in their biological and nutritional values due to the enzymatic degradation of meat components [4]. These moulds or yeasts could be spotted in different forms and colours on dried

${ }^{*}$ Corresponding author: Ibrahim Alhaji Salau

Department of Biological Sciences, Federal University Gusau, Zamfara State Nigeria.

Copyright $@ 2020$ Author(s) retain the copyright of this article. This article is published under the terms of the Creative Commons Attribution Liscense 4.0 
meats [5]. Earlier work by Okafor [6] revealed that a number of mould species has been isolated from dried meat and fish in Nigeria. Also, Berwal [7] and [8] reported that numerous strains of microscopic filamentous fungi isolated from the surface of various meat products showed in-vitro ability to produce toxic substances called mycotoxins and which may remain in the product for years, long after the mould has died.

Mycological quality of meat products plays an important role in an increasing public health issue all over the world. Microbial analysis must be carried out in dried meat aimed for human consumption because of its high mycoflora contamination due to inadequate handling practices, as well as fungi contamination during preservation [9].

It is imperative to note that the tremendous growth in the production and consumption of dried meat in the Kebbi state of Nigeria has made it a great concern to study and to know its mycological quality. This study therefore examines the mycological quality of dried meat sold in three (3) Emirates of Kebbi State, Nigeria.

\section{Material and methods}

\subsection{Sampling}

The State has four emirates namely: Argungu, Gwandu, Yawuri and Zuru. Each Emirate has between 4 - 10 local governments' areas. For the purpose of this study, three emirates (Argungu, Gwandu and Yawuri) were randomly selected by balloting; a system random sampling technique was used for sampling of meat in the markets of the selected local governments in the emirates.

\subsection{Selection of markets/Stores}

Markets from selected local government areas were identified through local government departments' of agriculture and traditional authorities.

\subsection{Collection of Samples}

A total of sixty three (63) samples of dried meat were obtained from markets. The samples (21 each) were collected from three agricultural zones, at different selling shades and centres respectively. Approximately $25 \mathrm{~g}$ representative sample was collected in small polyethylene packs according to Whitaker [10].

\subsection{Fungal isolation}

The isolation of fungi was carried out according to the agar dilution method as described [11]. One (1) grams from each sample were homogenized with $90 \mathrm{ml}$ of buffer peptone water and serial decimal dilutions $\left(10^{-1}\right.$ to $\left.10^{-4}\right)$ were performed. Fungal species were isolated on the Potato dextrose agar. The medium was poured into sterile Petri dish and $0.1 \mathrm{ml}$ of each sample suspension was spread-plated onto the PDA media. The plates were incubated for 5 to 7 days at $25^{\circ} \mathrm{C}$. Fungal isolates were sub-cultured on Sabouraud Dextrose agar (Oxoid, UK) and incubated for 5 to 7 days at $25^{\circ} \mathrm{C}$ for purification. Fungi were identified by using taxonomic schemes based on microscopic observation and culture appearance. The total fungal count for each plate was expressed as colony-forming units per gram of sample (CFU/g). Each genus or specie identified was then expressed as percentage (\%) of the total isolated fungi.

The total colonies of fungi were enumerated and results were reported in mean and average fungal counts as described $[12,13]$.

\subsection{Identification of Mold}

Identification of fungal Genera and the determination of each species of fungi were done using the keys of Klich [14] for Aspergillus spp. and Pitt and Hocking [12] for Penicillium sp. This was done by observing both microscopic characteristics and morphology of the colonies on PDA and SDA medium.

\subsection{Data Analysis}

The One-way ANOVA test was used, Means for the distribution of concentrations of Mycotoxins, comparison of means of TFC across sampling and overall (\%) for fungal species. The means were separated for test of significance by the Duncan's Multiple Range Test at $P=0.05$. 


\section{Results}

\subsection{Occurrence and distribution of fungi}

The Meat productsamples analyzed in this study had fungal contamination at varying levels. A total of 164 fungal isolates belonging to 8 identified species (Aspergillus niger, A. flavus, A. fumigatus, Fusarium, Cladospori, Rhizopus Absidia and Mucur) were recovered from the analyzed samples. Meat samples from three emirate of Kebbi State had the highest total fungal count of $3.4 \times 10^{4} \mathrm{cfu} / \mathrm{g}$ while those from Isa zone had the least fungal load, $1.1 \times 10^{3} \mathrm{cfu} / \mathrm{g}$ (Table 1).Aspergillus species were recovered from most of the samples in all locations with A. flavus (31.1\%) has the highest percentage, followed by A. niger (22.6\%) and Fusarium species (16.6\%). The least in occurrence were isolates of Rhizopus stolonifer and Absidia candidus with 4.9\% each. Aspergillus species were recovered from both samples site and in all locations, while Absidia candidus were detected. On the overall, the incidence of Aspergillus flavus was the highest (31.1\%) being significantly $(P<0.05)$ higher than the proportion of all other fungal species. Mucor racemosus with 5.5\%, although its incidence was not significantly $(P<0.05)$ different than the incidence of Rhizopus stolonifer and Absidia candidus. The results are presented in table 1.

Table 1 Occurrence and distribution of fungi contaminating Meat productswithin three Emirates in Kebbi state, Nigeria.

\begin{tabular}{|c|c|c|c|c|c|}
\hline \multirow{2}{*}{$\begin{array}{l}\text { Products } \\
\text { Zone }\end{array}$} & \multicolumn{4}{|l|}{ Dried Meat } & \multirow[t]{2}{*}{ Overall (\%) } \\
\hline & Gwandu & Argungu & Yawuri & Mean & \\
\hline *TFC (cfu/g) & $4.7 \times 10^{4}$ & $1.5 \times 10^{4}$ & $3.8 \times 10^{4}$ & $3.2 \times 10^{4}$ & \\
\hline \multicolumn{6}{|c|}{ Percentage (\%) of fungal species occurring in Meat products samples } \\
\hline Aspergillus flavus & 32.6 & 36.1 & 23 & & 31.1 \\
\hline Aspergillus niger & 14 & 19.4 & 31.4 & & 22.6 \\
\hline Aspergillus fumigates & 14 & 11.1 & 5.7 & & 9.1 \\
\hline Fusarium solani & 4.7 & 8.3 & 17.1 & & 14.6 \\
\hline Cladosporium spp. & 6.9 & 5.6 & 11.4 & & 7.3 \\
\hline Mucor racemosus & 9.3 & 11.1 & ---- & & 5.5 \\
\hline Rhizopus stolonifer & 11.6 & 5.6 & ---- & & 4.9 \\
\hline Absidia candidus & 6.9 & 2.8 & 11.4 & & 4.9 \\
\hline
\end{tabular}

\subsection{Fumonisins and Ochratoxin A Contaminating Meat Products}

The contaminated dried meat samples were found to contain Fumonisins B1 (FB 1 ) at concentrations ranging from 0.2 to $31.0 \mu \mathrm{g} / \mathrm{kg}$. The least concentration of $\mathrm{FB}_{1}$ was found in Gwandu emirate and highest concentrations were detected in samples obtained from Yawuri Emirate (Table 2). The incidence of the $\mathrm{FB}_{1}$ in Kebbi state shows that, Yawuri emirate has the highest incidence with 57.1\%, and the least were Gwandu emirate with 38.1\% only. However, the mean of FB 1 concentration in samples analyzed by locations were not significantly $(\mathrm{p}<0.05)$ different from each other. Out of 63 samples, only 4 (6.3\%) were contaminated with $>20 \mu \mathrm{g} / \mathrm{kg} \mathrm{FB} 1$ (maximum acceptable limit (MAL) recommended by the Standard Organization of Nigeria). FB 1 levels were not significantly ( $\mathrm{P}<0.05)$ different. Overall, 33 (52.4\%) of the 63 samples were contaminated with $\mathrm{FB}_{1}$, while 12 (19.1\%) of the samples had $\mathrm{FB}_{1}$ levels above the stipulated EU limit $4 \mu \mathrm{g} / \mathrm{kg}$. 
Table 2 Incidence of Fumonisins B1 Concentrations in Dried Meat in Three Emirates of Kebbi States,

\begin{tabular}{|c|c|c|c|c|c|}
\hline \multirow[b]{2}{*}{ Sampling location } & \multirow[b]{2}{*}{ N (\%) } & \multicolumn{4}{|c|}{ Fumonisins B1 concentration $(\mu \mathrm{g} / \mathrm{kg})$} \\
\hline & & Range & Mean & $N(\%)>4$ & $N(\%)>20$ \\
\hline Gwandu & $12 / 21(57.1 \%)$ & $0.8-21.2$ & $4.56^{\mathrm{a}}$ & $7 / 21(33.3 \%)$ & $2 / 21(9.5 \%)$ \\
\hline Argungu & $8 / 21(38.1 \%)$ & $0.2-29.6$ & $2.73^{\mathrm{a}}$ & $3 / 21(14.3 \%)$ & $1 / 21(4.8 \%)$ \\
\hline Yawuri & $13 / 21(61.9 \%)$ & $0.2-31.0$ & $2.38^{\mathrm{a}}$ & $2 / 21(9.5 \%)$ & $1 / 21(4.8 \%)$ \\
\hline Total & $33 / 63(52.4 \%)$ & $0.2-31.0$ & 3.22 & $12 / 63(19.1 \%)$ & $4 / 63(6.3 \%)$ \\
\hline
\end{tabular}

The presences of Ochratoxin A in meat products obtained are presented in Table 3. The frequencies of contamination are $71.4 \%, 47.6 \%$ and $47.6 \%$ for Gwandu, Argungu and Yawuri emirates respectively, concentration of the sample analysed ranged between $0.6-11.4,0.2-12.1$ and $0.4-14.0 \mu \mathrm{g} / \mathrm{kg}$ in the respective emirates, with mean of $3.36,1.95$ and 2.95 for the Gwandu, Argungu and Yawuri emirates respectively. There are no significant differences between the emirates.

Table 3 Ochratoxin A Concentration $(\mu \mathrm{g} / \mathrm{kg})$ of Dried Meat Collected from three Emirates

\begin{tabular}{lllll}
\hline Ochratoxin A & Emirates & $\begin{array}{l}\text { Frequency of } \\
\text { Contamination }\end{array}$ & $\begin{array}{l}\text { Range of concentration of } \\
\text { positive samples }(\boldsymbol{\mu g} / \mathbf{k g})\end{array}$ & $\begin{array}{l}\text { Mean } \pm \text { Standard } \\
\text { deviation }\end{array}$ \\
\hline \multirow{3}{*}{ DRIED MEAT } & Gwandu & $15 / 21(71.4 \%)$ & $0.6-11.4$ & $3.36 \pm 3.57 \mathrm{a}$ \\
& Argungu & $10 / 21(47.6 \%)$ & $0.2-12.1$ & $1.95 \pm 3.51 \mathrm{a}$ \\
& Yawuri & $10 / 21(47.6 \%)$ & $0.4-14.0$ & $2.95 \pm 4.72 \mathrm{a}$ \\
\hline \multicolumn{2}{l}{ Means followed by the same letter(s) do not differ significantly according to Duncan Multiple Range Test (DMRT) at 5\% level of significance }
\end{tabular}

\section{Discussion}

Meat surface is usually contaminated with a wide range of microorganisms. Due to its beneficial chemical composition (the content of water, proteins, peptides, amino acids, nucleo-tides, sugars, minerals and vitamins), the meat is a suitable medium for the development of all microorganisms [15].

The observed viable microbial count in Meat product samples analysed, were in line with reports by 0sho, [16], Inyang, [17], and Egbebi and Seidu, [18], that "Suya processed in Abeokuta (South Western Nigeria), Markurdi (Northern Nigeria), and Ado and Akure (South West Nigeria) respectively, have microbial contaminations. Similarly, this finding are in line with the reports by $[19,20]$ on the microbial hazards of poorly processed meat, the microbial hazards associated with, processing of suya meat, reported that processing water, meat processing slabs, utensils, spices and raw meat revealed contamination with potential pathogens such as $A$. flavusgroup that produce aflatoxins include $A$. flavus, A. parasiticus, A. nomius, A. tamari and A. bombycis.

Since no published work on the contamination of meat with fumonisins in Nigeria is available, it's going to be compared with other cereals investigated in Nigeria by other researchers. [21] Detected fumonisin B1 in $51 \%$ (55 out of 104 samples) of maize samples analysed with concentration range of 65 to $1830 \mu \mathrm{g} / \mathrm{kg}$, and mean value of $390 \mu \mathrm{g} / \mathrm{kg}$. In a similar study on the natural occurrence of fumonisins in pre-harvest maize in south western Nigeria, [22] reported $F$. verticillioides occurring in $89.3 \%$ of samples. Fumonisins B1 was reported to be the predominant toxin (frequency at $76.8 \%$, concentration between 70 and $1780 \mu \mathrm{g} / \mathrm{kg}$, and mean of $495 \mu \mathrm{g} / \mathrm{kg}$ ), while Fumonisin B2 was detected in $66 \%$ of the samples with a mean of $114 \mu \mathrm{g} / \mathrm{kg}$.

Detection of OTA in the samples can be a result of contamination by Aspegillus specie Production of OTA by black Aspergillusspecies has been reported [23]. Ochratoxin A has been found in wheat, corn, and oats having fungal infection and in cheese and meat products of animals consuming ochratoxin-contaminated grains [23]. A. ochraceusis found on 
dry foods, such as dried meat and smoked fish, soybeans, garbanzo beans, nuts, and dried fruit. OTA is immunosuppressive, teratogenic, genotoxic and mutagenic, and IARC [24] has classified it in group 2B as possibly carcinogenic to humans. OTA is a genotoxic carcinogen [25], and it was proposed that its levels in foods should be reduced to the lowest level that can be technologically attained. The Joint Expert Committee on Food Additives of the WHO [25] and FAO [26] set a provisional maximum intake of $100 \mu \mathrm{g} / \mathrm{kg}$ body weight (bw), while the Scientific Committee on Food of the European Union proposed that the maximum daily intake of OTA should not exceed $5 \mu \mathrm{g} / \mathrm{kg}$ bw [25].

Therefore Food producers must follows the principles of good manufacturing practice and take preventive measures in order to reduce the growth of microscopic filamentous fungi and the production of their toxic metabolites in the final products.

\section{Conclusion}

In conclusion, the present work indicated that the examined dried meats were contaminated with several moulds especially of the genus Aspergillus. Many of these moulds are capable of producing mycotoxin such as aflatoxins, ochratoxin and fumonisins. These findings indicate that there may be a risk of human exposure to mycotoxins through the consumption of the dried meat. Strict hygienic measures must be applied during the processing and storage of the meat samples and calls for concerted efforts on the part of relevant authorities to check the trend, since it is a public health challenge.

\section{Compliance with ethical standards}

\section{Acknowledgments}

The authors express sincere thanks and appreciation to Tertiary Education Trust Find [TETFUND] Abuja for research sponsorship and Federal University Birnin-Kebbi, Nigeria for the Laboratory space provided to carry out this research work.

\section{Disclosure of conflict of interest}

The authors declare that they have no competing interests.

\section{References}

[1] Olusola FP, Omojola AB. Relevance of dried meat product (Kundi), an Intermediate Moisture Meat (IMM), for food security. 2010.

[2] Okaka JC, Akobundu ENT, Okaka CAN. Food and Human Nutrition, an Integrated Approach. O. J. C. Academic Pub. Enugu, Nigeria. 2006.

[3] Ostry V, Ruprich J. The occurence of moulds in meat and meat products (II). How is the actual status in The Czech Republic (In Czech).Hygiena. 2001; 6: 17-21.

[4] Amusa NA, Kehinde IA, Ashaye OA. Biodeterioration of the African star Apple (Artocarpuscommunis) in storage and its effects on the nutrient composition. African Journal of Biotechnology. 2002; 1(2): 57- 60.

[5] Lowry PO, CO Gill. Temperature and water activity minimal for growth of spoilage moulds from meat. Journal of Applied Microbiology. 2008; 1(56): 193-198.

[6] Okafor N. Fungi associated with mouldy dried fish. Nig. J. Sci. 1968; 6(2): 500-549.

[7] Berwal D. Basic Food Microbiology. West Pat ConnecticuitAvi Publishing Company Inc. 1991.

[8] Oladejo DA, Adebayo-Tayo BC. Moulds, Proximate, mineral composition and mycotoxin contamination of Banda ("Kundi/Tinco") sold in Ibadan, Oyo State, Nigeria. AUJ.T. 2011; 15(1): 32-40.

[9] Salau IA, Shehu K, Muhammad S, Umar RA. Aflatoxin Contamination of Stored Groundnut Kernel in Sokoto State, Nigeria. Greener Journal of Agricultural Sciences. 2016; 6(10): 285-293.

[10] Whitaker TB. Standardisation of mycotoxin sampling procedure an urgent necessity. Food Contr. 2003; 14:233237. 
[11] Pittet A. Natural occurrence of mycotoxins in foods and feeds: an updated review. Revue Medicine Veterinary. 1998; 149: $479-492$.

[12] Pitt J,Hocking A. Fungi and Spoilage (2nd ed.). London, N.Y. Blackie Academy and Professional. 1997.

[13] Dachoupakan C, Ratomahenina Martinez R, Guiraud JP, Baccou JC, Schorr Galindo S. Study of the phenotypic and genotypic biodiversity of potentially ochratoxigenic black aspergilli isolated from grapes. International Journal of Food Microbiology. 2009; 132:14-23.

[14] Klich MA. Introduction; economic and medical importance of Aspergillus. In Identification of common Aspergillus species. 2002; 1-16.

[15] Shamsuddeen U,Ameh JB. Survey on the possible critical control points in kilishi (a traditional dried and grilled meat snack) produced in kano. International Journal of Bioscience. 2008; 3(2): 34- 38.

[16] Osho AT. Evaluation of bacterial contamination of grilled meat (Suya) processed in Abeokuta. Undergraduate research project. Development of Nutrition and Dietetics. University of Agriculture Abeokuta. 2004; 49.

[17] Inyang CU, Inyor MA, Uma EN. Bacteriological quality of a smoked meat product (suya). Nig. Food. J. 2005; 23: 239-242.

[18] Egbebi AO,Seidu KT. Microbiological evaluation of Suya (dried smoked meat) sold in Ado and Akure, South West Nigeria. European Journal of Experimental Biology. 2011; 1(4):1-5.

[19] Edema MA, Osho AT,Diala CI. Evaluation of Microbial Hazards associated with the processing of Suya (a grilled meat product). Scientific Res. and Essays. 2008; 3(12): 621-626.

[20] Ologhobo AD, Omojola AB, Ofongo ST, Moiforay S, Jibir M. Safety of street vended meat products - chicken and beef suya. Afr. J. Biotech. 2010; 9:4091-4095.

[21] Bankole SA,Adebajo A.Mycotoxins in food in West Africa: current situation and possibilities of controlling it. American Journal of Biotechnology. 2003; 2(9):254-263.

[22] Bankole SA,Mabekoje 00. Mycoflora and Occurrence of Aflatoxin B1 in Dried Yam Chips from Markets in Ogun and Oyo States, Nigeria. Mycopathologia. 2004; 157(1):111-115.

[23] Amadi JE,Adeniyi DO.Mycotoxin production by fungi isolated from stored grains. American Journal of Biotechnology. 2009; 8(7):1219-1221.

[24] IARC (International Agency for Research on Cancer). Some traditional herbal medicines, some mycotoxins, naphthalene and styrene. IARC Monography Evaluation Carcinogen Risks of Human. 2002; 82: 1-56.

[25] FAO (Food and Agriculture Organization). United Nations Food and Agricultural Organization, Evaluation of Certain Mycotoxins in Food: Fifty-sixth Report of the Joint FAO/WHO Expert Committee on Food Additives, World Health organization, Geneva. 2006.

[26] WHO (World Health Organization).Mycotoxin in African foods: Implications to Food Safety and Health. AFRO Food Safety Newsletter, World Health Organization Food safety. 2013. 